\title{
Clinical and laboratorial study of HPV infection in men infected with HIV
}

\author{
Giuseppe Figliuolo, Jusimara Maia, Alex P. Jalkh, Angelica E. Miranda, Luiz C.L. Ferreira
}

Fundação da Medicina Tropical Dr. Heitor Vieira Dourado, Manaus, Brazil

\section{ABSTRACT}

Objectives: To determine the prevalence of precursor lesions of penile cancer, to establish the concordance of diagnostic techniques (PCR, Hybrid Capture (HC) and peniscopy with acetic acid 5\%) in the diagnosis of Human Papilloma Virus (HPV) of the penis of men infected with HIV and to evaluate the influence of the immune status.

Patients, Methods and Results: 276 men were studied, with a median age of 34.6 years. Prevalence of High Risk HPV, Low Risk HPV and infection with both, according to HC, was $43 \%, 32 \%$ and $22 \%$, respectively. PCR showed $50 \%$ of positivity for HPV DNA. Peniscopy was positive in $27 \%$ of individuals. Peniscopy showed good specificity and low sensitivity for the detection of penile HPV, and low concordance with PCR. Men with white lesions had a 3.6 higher relative risk of positivity for HPV. The most common clinical lesion observed was vegetation, identified in 29\% of patients. PCR and HC techniques showed high sensitivity for HPV DNA and there was an excellent correlation between them. Immunosuppressed individuals with $\mathrm{CD} 4<200$ cells/mm3 had the highest prevalence of premalignant lesions that were observed in $10 \%$ of the studied individuals.

Conclusions: Peniscopy was important for identification and treatment of subclinical lesions. PCR and HC techniques were sensitive methods for the detection of HPV DNA with high concordance. Severely immunosuppressed individuals showed a higher prevalence of pre-malignant lesions of the penis.

\section{ARTICLE INFO}

\section{Key words:}

DNA Probes; HPV;

Men; HIV

Int Braz J Urol. 2012; 38: 411-18

Submitted for publication: January 01, 2011

Accepted after revision: November 09, 2011

\section{INTRODUCTION}

In the literature, several studies point out that $10 \%$ to $20 \%$ of sexually active adults have HPV infection, although only $1 \%$ presents classic condyloma and $2 \%$ visible lesions after acetic acid application (1). According to world literature, it is rational to expect the existence of 3 to 6 million males infected with HPV (2).

The relationship between HPV infection and cervical cancer is well established and there are strong evidences that it may also be implicated in the etiology of anal and genital cancer (3).
The studies related to the determination of prevalence of HPV infection in males are very important, since they can present a subclinical and asymptomatic infection and become potential source of infection of HPV to their male or female sexual partners (4).

In view of all these facts, our study was designed to determine the prevalence of precursor lesions of penile cancer, to establish the concordance among different diagnostic techniques (PCR, Hybrid Capture (HC) and Peniscopy with acetic acid 5\%) in the diagnosis of infection with the Human Papilloma Virus (HPV) of the penis of 
HIV positive males and to evaluate the influence of the immunologic status on the occurrence of the lesions.

\section{MATERIAIS AND METHODS}

This is a cross-sectional descriptive study of men affected with HIV attended at the Fundação de Medicina Tropical Dr. Heitor Vieira Dourado (FMT-HVD). Data including demographic, epidemiologic and clinical characteristics of patients were collected. Physical examination (urological inspection and peniscopy with acetic acid 5\%), molecular biological tests (PCR in house and Hybrid Capture II, Digene \& $\mathrm{Co}^{\circledR}$ ) and conventional histopathology study were also performed. Criteria for inclusion were: HIV positive males, with $\geq 18$ years old, who provided written informed consent to join the study. Criteria for exclusion were: HIV negative males, Indians, psychiatric patients and those that didn't complete all steps of the study. Data were collected at Epi Info ${ }^{\circledR}$ version 6.04 platform and the statistical analysis was made through Statistical Package for Social Sciences ${ }^{\circledR}$ (SPSS) version 16.0 for Windows.

Patients lied in supine position in order to be submitted to the urological and scrotal inspection. A surgical brush with saline was rubbed against the foreskin, balanopreputial sulcus, glans and navicular fossa of the penis. The brush was immersed in an Eppendorf vial containing $1 \mathrm{~mL}$ of T1 buffer (commercial kit for nuclear extraction Spin Tissue-Macherey-Nagel $\left.{ }^{\circledR}\right)$. The vial was tightly closed and sent to the laboratory, where was maintained at $-70^{\circ} \mathrm{C}$ until PCR analysis.

Another brush was used to Hybrid Capture (HC) for High and Low Risk HPV, and it was stored in an appropriate kit.

After the cytological collection, we proceeded with peniscopy and penile and scrotal inspection. A gauze soaked with acetic acid 5\% was placed around the penis for 10 minutes. Positive lesions (white lesions) were biopsied, except in patients with previous histopathological or laboratorial diagnosis or that didn't allow the procedure. The samples were fixed in buffered formalin 10\% and were sent to histopathological studies.
For statistical analysis, it was used Pearson's Chi-Square test with Yates correction whenever necessary; Fisher's exact test was used to categorical variables for values under 5 and significance analysis including Odds Ratio (OR) and 95\% confidence intervals was performed. Significance was established for $p<0.05$ (5\%).

For concordance analysis, it was used the kappa (k) associative test.

\section{RESULTS}

Two hundred and seventy six HIV-positive male patients older than 18 years old were included. Median age was 34.6 years. Table- 1 depicts socio-demographics characteristics of patients. Table-2 shows the variables related to sexual behavior, use of condoms and previous STDs and Table- 3 those related to HIV virus.

Peniscopy was positive for white lesions in 27\% of patients. The most frequent lesion was vegetation (29\%) (Table-4). Biopsy was obtained in $22 \%$ of participants; some of them had more than one lesion and a total of 75 fragments of skin were collected for conventional histopathological study (Table-5). Pre-malignant lesions were observed in 10\% of patients (Table-6), and most of them (59\%) had CD $4<200$ cells/mm3.

According to HC, the prevalence for High Risk, Low Risk and both High and Low Risk HPV infection were 43\%, 32\% and 22\%, respectively. PCR had 50\% of positivity for HPV DNA.

The concordance between peniscopy and PCR was observed in $62 \%$ of samples, revealing a "weak concordance" according to kappa associative test $(\mathrm{k}=0.2317)$. Patients with white lesions observed at peniscopy had a 3.6 higher risk of HPV infection.

Peniscopy was considered a diagnostic test with high specificity (86\%) and low sensitivity (37\%). Positive and negative predictive values were $73 \%$ and 58\%, respectively. Exam accuracy was $62 \%$.

When PCR and HC for High Risk and Low Risk HPV results were compared, 88\% of samples showed similar results. There was an "excellent concordance" between the different techniques according to kappa associative test $(\mathrm{k}=0.7522)$. 
Table 1 - Socio-demographic variables of 276 men with HIV+/AIDS.

\begin{tabular}{|c|c|c|}
\hline Demographic indices & $\mathrm{N}$ & $\%$ \\
\hline \multicolumn{3}{|l|}{ Age } \\
\hline $18-29$ years & 101 & 36 \\
\hline $30-49$ years & 151 & 55 \\
\hline$\geq 50$ years & 24 & 9 \\
\hline
\end{tabular}

\section{Race/Colour}

Brown

White

47

Black

7

Yellow

\section{Marital status}

Single

Married

Fixed partner

Divorced

Widow

\section{Education}

Illiterate

Primary

Secondary

Terciary

52

Use of unlawfully drugs

Yes

No

Smoking

Yes 
Table 2 - Distribution of sexual behavior variables, use of condoms and previous STDs of 276 HIV+/AIDS males.

\begin{tabular}{|c|c|c|}
\hline Variables & N & $\%$ \\
\hline \multicolumn{3}{|l|}{ Sexual Orientation } \\
\hline Homosexual & 101 & 36 \\
\hline Heterosexual & 107 & 39 \\
\hline Bisexual & 68 & 25 \\
\hline \multicolumn{3}{|c|}{ Beginning of sexual activity } \\
\hline$\leq 15$ years & 105 & 55 \\
\hline $15-19$ years & 151 & 38 \\
\hline$\geq 20$ years & 20 & 7 \\
\hline \multicolumn{3}{|c|}{$\mathbf{N}^{0}$ of sexual partners during last year } \\
\hline 0 & 24 & 9 \\
\hline 1 & 97 & 35 \\
\hline $2-9$ & 93 & 34 \\
\hline$\geq 10$ & 62 & 22 \\
\hline \multicolumn{3}{|c|}{ Use of condom prior to HIV+ } \\
\hline Occasionally & 230 & 85 \\
\hline Always & 7 & 3 \\
\hline Never & 39 & 14 \\
\hline \multicolumn{3}{|l|}{ Use of condom after HIV+ } \\
\hline No sexual relations & 35 & 13 \\
\hline Occasionally & 28 & 10 \\
\hline Always & 206 & 75 \\
\hline Never & 7 & 2 \\
\hline \multicolumn{3}{|l|}{ Prior STDs* } \\
\hline Yes & 177 & 64 \\
\hline No & 99 & 36 \\
\hline
\end{tabular}

*sexually transmitted diseases. 
Table 3 - Variables associated to the presence of HIV virus.

\begin{tabular}{|c|c|c|}
\hline Variables & N & $\%$ \\
\hline \multicolumn{3}{|l|}{ Time to HIV diagnosis } \\
\hline$\leq 3$ years & 198 & 72 \\
\hline 4-6 years & 38 & 14 \\
\hline $7-9$ years & 15 & 5 \\
\hline$\geq 10$ years & 25 & 9 \\
\hline \multicolumn{3}{|c|}{ Opportunistic Diseases Associated to HIV } \\
\hline Yes & 134 & 48 \\
\hline No & 142 & 52 \\
\hline \multicolumn{3}{|l|}{ Use of ART* } \\
\hline Yes & 152 & 55 \\
\hline No & 124 & 45 \\
\hline \multicolumn{3}{|l|}{ ART $^{*}$ time of use } \\
\hline$<1$ year & 79 & 52 \\
\hline $1-2$ years & 16 & 10 \\
\hline 2-3 years & 12 & 8 \\
\hline$>3$ years & 45 & 30 \\
\hline \multicolumn{3}{|l|}{ Lymphocyte count TCD4 } \\
\hline$<200$ & 103 & 37 \\
\hline $200-349$ & 68 & 25 \\
\hline $350-500$ & 41 & 15 \\
\hline$>500$ & 40 & 15 \\
\hline No exam & 24 & 9 \\
\hline \multicolumn{3}{|l|}{ Viral load } \\
\hline Undetectable & 68 & 25 \\
\hline$<30.000$ & 108 & 39 \\
\hline$>30.000$ & 71 & 26 \\
\hline Superior limit (> 500.000) & 4 & 1 \\
\hline No exam & 25 & 9 \\
\hline \multicolumn{3}{|l|}{ HIV infection phase } \\
\hline AIDS & 179 & 65 \\
\hline Carrier & 97 & 35 \\
\hline
\end{tabular}

*antiretroviral therapy 
Table 4 - Distribution of dermatological lesions observed in 75 positive peniscopies. After: Rook's 2010 (5).

\begin{tabular}{lcc}
\hline Peniscopy Lesion & N & $(\%)$ \\
\hline Vegetation & 25 & 29 \\
White lesion & 13 & 15 \\
Ulcer & 10 & 12 \\
Papule normochromic & 13 & 15 \\
Crust & 1 & 1 \\
Papule Hypochromic & 4 & 5 \\
Papule Hyperchromic & 4 & 5 \\
Macula hypochromic & 9 & 10 \\
Macula hyperchromic & 3 & 4 \\
Eritema & 1 & 1 \\
Hyperchromic Plate & 2 & 2 \\
\hline Total & 85 & 100 \\
\hline
\end{tabular}

\section{DISCUSSION}

The prevalence of HPV in our study was higher than of the study of Goldstone et al. They evaluated 602 HIV negative males who were engaged in sex with other males and observed a prevalence of $18.2 \%$ of HPV infection of the penis using also PCR (6).

Peniscopy showed high specificity and low sensitivity. However, most studies showed a weak specificity of the exam and also a good sensitivity (7-9). We believe that our results were biased due to the high prevalence of HPV in the studied population (around 50\%), explaining the good specificity, and that most of the patients had subclinical or latent infection with HPV, that impaired the identification through peniscopy, only with biomolecular techniques, explaining the low sensitivity.

Some risk characteristics for HPV infection of penis of HIV positive males were identified in our study, including heterosexual behavior (higher rate of penile HPV infection compared to bisexuals and homosexuals, probably due to the high rate of female infection in our population, demonstrated in several studies done in Manaus (10-12).

PCR and HC techniques had high concordance and sensitivity for the detection of HPV. Rodrigues et al. (13) demonstrated that HC and PCR techniques for the detection of HPV in clinical samples had a fair concordance, including conventional and real time techniques $(\mathrm{k}=0.338)$. When they compared conventional PCR with real time PCR they observed an almost perfect concordance $(\mathrm{k}=0.818)$.

There are very few studies related to intraepithelial neoplasms or penile cancer of HIV positive men. Kreuter et al. studied 263 HIV-positive homosexual men and found penile intraepithelial neoplasms of penis in $11(4.2 \%)$ and of anus in 156 (59.3\%) (14).

The limitations of our study included the small size of sample that prevented a strong association among the techniques. The study was conducted in an AIDS ambulatory. However, most 
Table 5 - Distribution of histopathological findings of patients with clinical lesions detected.

\begin{tabular}{lll}
\hline Histopathological Findings & N & (\%) \\
\hline Angioceratoma & 1 & 1 \\
Chronic inespecifc balanitis & 2 & 2 \\
Inespecific ulcerated balanitis & 1 & 1 \\
Inespecific chronic balanopostitis & 2 & 2 \\
Condyloma Acuminata & 19 & 27 \\
Flat Condyloma & 1 & 1 \\
Epidermodysplasia & 2 & 2 \\
Nonspecific chronic eczema & 1 & 1 \\
Hypermelanose & 1 & 1 \\
High grade intra-epitelial lesion (HSIL) & 4 & 6 \\
Fungal infection & 1 & 1 \\
Scleroathrofic lichen & 2 & 2 \\
Lichen planus & 1 & 1 \\
Low grade Intra-epitelial lesion (LSIL) & 1 & 25 \\
Molluscum Contagiosum & 18 & 9 \\
Melanocytic nevi & 6 & 1 \\
Bowenoid papulosis & 1 & 7 \\
Chronic inespecific postitis & 1 & 1 \\
\hline No significative alterations & 5 & 1 \\
\hline
\end{tabular}

Table 6 - Distribution of histopathological findings of 27 pre-malignant lesions.

\section{Pre-malignant lesions}

Epidermodysplasia Verruciformis Like

High grade intra-epitelial lesion (HSIL)

04

Low grade Intra-epitelial lesion (LSIL)

17

Bowenoid papulosis

03

Bowenoid papulosis+ LSIL+Bowenoid papulosis

01 
HIV+/AIDS patients from Amazonas are attended at FMT-HVD, which we believed allowed the study of a significant sample of patients.

We believe that the present results can be used to delineate preventive programs for early detection of penile cancer, in individuals with higher risk, including immunosuppressed patients. Diagnosis and treatment of male partners infected with HPV would also allow a reduction of sexually transmitted diseases.

\section{CONCLUSIONS}

Prevalence of DNA HPV was approximately $50 \%$.

Peniscopy proved to be a high specific and low sensitive exam.

Concordance of peniscopy and PCR for the detection of HPV was low.

Concordance of PCR and HC for HPV detection was excellent.

We observed a prevalence of $10 \%$ of patients with pre-malignant lesions determined by histopathological studies and that most of them were severely immunosuppressed (TCD $4<200$ cells $\left./ \mathrm{mm}^{3}\right)$.

\section{CONFLICT OF INTEREST}

None declared.

\section{REFERENCES}

1. Gollnick H, Barasso R, Jappe U, Ward K, Eul A, Carey-Yard M, Milde K: Safety and efficacy of imiquimod $5 \%$ cream in the treatment of penile genital warts in uncircumcised men when applied three times weekly or once per day. Int J STD AIDS. 2001; 12: 22-8.

2. Silverberg MJ, Ahdieh L, Munoz A, Anastos K, Burk RD, CuUvin S, et al.: The impact of HIV infection and immunodeficiency on human papillomavirus type 6 or 11 infection and on genital warts. Sex Transm Dis. 2002; 29: 427-35.

3. Internacional Agency for Research on Cancer (IARC). Working Group on the Evaluation of Carcinogenic Risks to Humans. Human papillomaviruses. IARC Monogr Eval Carcinog Risk Hum 2008; 1-636.
4. Olsson SE, Kjaer SK, Sigurdsson K, Iversen OE, HernandezAvila M, Wheeler CM, et al.: Evaluation of quadrivalent HPV 6/11/16/18 vaccine efficacy against cervical and anogenital disease in subjects with serological evidence of prior vaccine type HPV infection. Hum Vaccin. 2009; 5: 696-704.

5. Rook's textbook of dermatology. Nomeclatura do Comitê da liga Internacional da Sociedade de Dermatologia; 2010.

6. Goldstone S, Palefsky JM, Giuliano AR, Moreira ED Jr, Aranda $\mathrm{C}$, Jessen $\mathrm{H}$, et al.: Prevalence of and risk factors for human papillomavirus (HPV) infection among HIV-seronegative men who have sex with men. J Infect Dis. 2011; 203: 66-74.

7. Carvalho JJM. Prevalência e padronização diagnóstica da infecção genital pelo HPV em homens atendidos em clínica urológica. São Paulo. Tese (mestrado). FMSCSP; 1999, 109p.

8. Carvalho JJM. Identificação do grupo de risco em pacientes com infecção pelo HPV com diagnóstico pela peniscopia confirmado pelo teste de biologia molecular. São Paulo. Tese (Doutorado). FMSCSP; 2002, 63p.

9. Chaves JHB, Vieira TKB, Ramos JS, Bezerra AFS. Peniscopia no rastreamento daslesões induzidas pelo papilomavirus humano. Rev Bras Clin Med. 2011; 9: 30-5.

10. Souza PM. Detecção do Papilomavírus Humano (HPV) na Cérvice Uterina de Pacientes HIV positivas e em portadoras de AIDS. Manaus. Tese (Mestrado). Fundação de Medicina Tropical do Amazonas; 2004.

11. Brock MF. Alterações Colpocitológicas em pacientes portadoras do Vírus HIV atendidas na Fundação de Medicina Tropical do Amazonas. Tese (Mestrado). Fundação de Medicina Tropical do Amazonas; 2005.

12. Corrêa GJ. Prevalência do Papilomavírus Humano (HPV) em mulheres portadoras de lesões intra-epiteliais escamosas de alto grau e carcinoma epidermóide invasor de colo uterino. Tese (Mestrado). Fundação de Medicina Tropical do Amazonas; 2005.

13. Rodrigues AD, Cantarelli VV, Frantz MA; Pilger DA, Pereira FS. Comparação das técnicas de captura de híbridos e PCR para a detecção de HPV em amostras clínicas. J Bras Patol Med Lab 2009; 45 (6):457-62.

14. Kreuter A, Brockmeyer NH, Weissenborn SJ, Gambichler T, Stücker M, Altmeyer P, et al.: Penile intraepithelial neoplasia is frequent in HIV-positive men with anal dysplasia. $\mathrm{J}$ Invest Dermatol. 2008; 128: 2316-24.

\section{Correspondence address} Dr. Giuseppe Figliuolo Fundação de Medicina Tropical Dr. Heitor Vieira Dourado, Manaus, Brazil Parque Tropical, Rua 08, 28-B / 1104, Edifício: Nápoles. Bairro: Parque 10 Manaus, AM, 69055-747, Brazil E-mail: gf_urol@hotmail.com 